\title{
Mine de fer de Rivèrenert
}

\section{(2) OpenEdition \\ Journals}

Édition électronique

URL : http://journals.openedition.org/adlfi/11057

ISSN : 2114-0502

Éditeur

Ministère de la culture

Référence électronique

" Mine de fer de Rivèrenert », ADLFI. Archéologie de la France - Informations [En ligne], Midi-Pyrénées, mis en ligne le 01 mars 1997, consulté le 21 avril 2019. URL : http://journals.openedition.org/ adlfi/11057

Ce document a été généré automatiquement le 21 avril 2019

(C) Ministère de la Culture et de la Communication, CNRS 


\section{Mine de fer de Rivèrenert}

Identifiant de l'opération archéologique :

Date de l'opération : 1991 (PR)

Inventeur(s) : Dubois Claude

1 Dans le cadre de ses recherches de troisième cycle, Catherine Verna a trouvé une mention du XIV ${ }^{\mathrm{e}}$ s. concernant la mine de fer de Rivèrenert alors qu'un plan daté de 1943 fait apparaître des «vieux travaux romains » dans la partie haute de l'exploitation. Les prospections menées dans cette mine pour retrouver les vestiges des anciens travaux d'extraction ont nécessité le recours aux techniques de l'escalade et de la spéléologie (J-P. Calvet) pour équiper les cheminées d'accès au niveau $+37 \mathrm{~m}$.

2 Ici, l'exploitation moderne a recoupé plusieurs anciens travaux : une galerie courbe haute de $1,70 \mathrm{~m}$ et large de $1,30 \mathrm{~m}$, qui suit un miroir de faille, un boyau entièrement remblayé et un dépilage ouvert à la pointerolle. Aucun mobilier archéologique n'a été retrouvé.

\section{INDEX}

Index chronologique : Empire romain, Moyen Âge**

Index géographique : Midi-Pyrénées, Ariège (09), Rivèrenert

operation Prospection (PR) 